\title{
Degradation of the Herbicide Naproanilide, 1-(2-Naphthoxy)propionanilide, in Flooded Soils under Oxidative and Reductive Conditions
}

\author{
Masami Oyamada,* Keiichi Igarashi** and Shozo KuwatsuKa*** \\ *,***Department of Agricultural Chemistry, Nagoya University, \\ Furo-cho, Chikusa-ku, Nagoya 464, Japan \\ **Research Center, Mitsui Toatsu Chernicals Inc., 1190 \\ Kasama-cho, Totsuka-ku, Yokohaina 247, Japan
}

(Received January 23, 1980)

\begin{abstract}
The degradation of ${ }^{14} \mathrm{C}$-naproanilide [1-(2-naphthoxy)propionanilide] labelled at the naphthalene-ring in three different soils under oxidative (aerobic) and reductive (anaerobic) flooded conditions was studied in the laboratory. ${ }^{14} \mathrm{C}$-Naproanilide was rapidly degraded under both conditions, and the difference in rates among the different soils was small. The degradation products in the organic solvent extracts detected by thin layer chromatography were composed of 1-(2-naphthoxy)propionic acid, the major product, and methyl 1(2-naphthoxy)propionate, 2-naphthol, 2-hydroxy-1,4-naphthoquinone and 2,3-, 2, 6- and 2,7-dihydroxynaphthalenes, minor products. A larger amount of ${ }^{14} \mathrm{CO}_{2}$ was liberated under oxidative than reductive conditions. Soil-bound residues of the radioactive materials in the two mineral soils increased to a larger extent under oxidative than reductive conditions, but the increase under both conditions was small in volcanic ash soil.
\end{abstract}

\section{INTRODUCTION}

The herbicide naproanilide, 1-(2-naphthoxy) propionanilide, developed by Mitsui Toatsu Chemicals Inc. is used to control most annual and perennial weeds except barnyard grass in upland and rice paddy fields. This herbicide has high selectivity among rice plants and many weeds in paddy fields. Its herbicidal activity is not greatly affected by environmental conditions such as temperature, soil type, and movement of irrigation water. ${ }^{1)}$

In the present paper, the degradation of naproanilide in three different soils was studied in the laboratory under oxidative- and reductive-flooded conditions.

\section{MATERIALS AND METHODS}

\section{Radioactive Naproanilide}

${ }^{14} \mathrm{C}$-Naproanilide, uniformly labelled at the

* Present address: Agricultural Research laboratory, Mitsui Toatsu Chemicals Inc., 500 Nishikubo, Chigasaki, Kanagawa 253, Japan naphthalene-ring, was synthesized by Daiichi Pure Chemicals Co. Ltd. and supplied by Mitsui Toatsu Chemicals Inc. The specific radioactivity was $1.0 \mathrm{mCi} / \mathrm{mmol}$ and the radioactive purity was more than $99 \%$.

\section{Authentic Chemicals}

The authentic compounds for thin layer chromatography are shown in Table 1. The compounds were prepared as follows:

1-(2-Naphthoxy)propionic acid (NPA) was prepared from $\beta$-naphthol and $\alpha$-chloropropionic acid by condensation under alkaline conditions. The compound obtained was recrystallized from $\mathrm{CCl}_{4}, \mathrm{mp} 106-107^{\circ} \mathrm{C}$. Calcd: C 72.22, H 5.56. Found: C 72.25, H 5.54.

This acid was methylated with methanol by dehydration to obtain methyl 1-(2-naphthoxy)propionate (NPA-Me), which was recrystallized from $n$-hexane, $\mathrm{mp} 57.5-58.5^{\circ} \mathrm{C}$. Calcd: C 73.04, H 6.09. Found: C 73.10, H 6.02 .

Naproanilide, 1-(2-naphthoxy) propionanilide, was prepared by reacting 1-(2-naphth- 
Table $1 R f$ values of authentic compounds on thin layer chromatogram.

\begin{tabular}{lccc}
\hline \multirow{2}{*}{ Compounds } & \multicolumn{3}{c}{ Solvent system* } \\
\cline { 2 - 4 } & $\mathrm{A}$ & $\mathrm{B}$ & $\mathrm{C}$ \\
\hline Naproanilide & 0.67 & 0.97 & 0.75 \\
$\begin{array}{c}\text { 1-(2-Naphthoxy)- } \\
\text { propionic acid }\end{array}$ & 0.04 & 0.28 & 0.17 \\
$\begin{array}{c}\text { Methyl 1-(2-naphth- } \\
\text { oxy)propionate }\end{array}$ & 0.78 & 0.98 & 0.89 \\
$\begin{array}{l}\text { 2-Naphthol } \\
\text { 2,3-Naphthalenediol }\end{array}$ & 0.57 & 0.85 & 0.59 \\
2,6-Naphthalenediol & 0.26 & 0.76 & 0.36 \\
$\begin{array}{l}\text { 2,7-Naphthalenediol } \\
\text { 2-Naphthylamine }\end{array}$ & 0.24 & 0.72 & 0.33 \\
2-Hydroxy-1,4- & 0.45 & 0.90 & 0.59 \\
naphthoquinone & 0.12 & 0.31 & 0.25 \\
\hline
\end{tabular}

* Solvent systems; A: Cyclohexane-ethyl acetate $(2: 1 \mathrm{v} / \mathrm{v}), \mathrm{B}$ : Chloroform-methanol $(4: 1$ $\mathrm{v} / \mathrm{v}$ ), C: Benzene-acetone-acetic acid (200: $40: 1 \mathrm{v} / \mathrm{v})$.

oxy)propionic acid with aniline in the presence of $\mathrm{PCl}_{3}$, and recrystallized from toluene, $\mathrm{mp}$ 127-128 ${ }^{\circ} \mathrm{C}$. Calcd: C 78.35, H 5.84, N 4.81 . Found: C 78.40, H 5.82, N 4.79 .

The other authentic chemicals were obtained commercially.

\section{Soil Samples}

Anjo soil, a mineral soil with kaolin clay minerals, obtained from a paddy field of the Paddy Field Experimental Farm, Aichiken Agricultural Research Center in Anjo, Aichi Prefecture; Nagano soil, a mineral soil with montmorillonite clay minerals, from a paddy field of Nagano Agricultural Experiment Station, Nagano, Nagano Prefecture; and Tochigi soil, a humic volcanic ash soil, from a paddy field near Utsunomiya, Tochigi Prefecture, were used. Wet samples of these soils collected from furrow layer of the paddy fields in winter were crushed well, and passed through a $2 \mathrm{~mm}$ sieve. The physicochemical properties of these soil samples are shown in Table 2.

\section{Soil Conditioning (Pre-incubation) 4.1 Oxidative-flooded conditions}

Twenty-five grams of Anjo and Nagano soil, and $12.5 \mathrm{~g}$ of Tochigi soil were placed in a 300-ml Erlenmeyer flasks, and flooded with water up to $0.5 \mathrm{~mm}$ deep. The soil layer was also about $0.5 \mathrm{~cm}$ deep. The mouth of each. flask was covered with aluminum foil and the soil was incubated at $30^{\circ} \mathrm{C}$ for 5 weeks. All other processes were similar to that reported in our previous paper. ${ }^{2)}$ The Eh values of the soils ranged between +500 and $+600 \mathrm{mV}$ after pre-incubation.

\subsection{Reductive-flooded conditions}

The same amounts of the soils as described above were placed in test tubes $(2 \mathrm{~cm}$ i.d. and $20 \mathrm{~cm}$ long). The soil (about $7 \mathrm{~cm}$ deep) was flooded to a depth of $3 \mathrm{~cm}$, and the mouth of each tube was capped with a rubber stopper. The soil was incubated in the same way as described for the oxidative conditions. The Eh values of Anjo, Nagano, and Tochigi soils after pre-incubation were $-270,-250$, and $-100 \mathrm{mV}$, respectively.

\section{Application and Incubation of ${ }^{14} \mathrm{C}$-napro- anilide \\ ${ }^{14} \mathrm{C}$-Naproanilide dissolved in $0.5 \mathrm{ml}$ of} acetone was added to the pre-incubated soil at $10 \mathrm{ppm}$ on a dry soil basis, and mixed with the soil. The soil was incubated for designated periods under the same conditions as described for pre-incubation. For measurement of ${ }^{14} \mathrm{CO}_{2}$ liberated under oxidative-flooded conditions, a rubber stopper with inlet and outlet

Table 2 Properties of soil samples used.

\begin{tabular}{lccccccccc}
\hline \multicolumn{1}{c}{ Soil } & $\begin{array}{c}\text { Maximum water } \\
\text { holding } \\
\text { capacity }(\%)\end{array}$ & $\begin{array}{c}\mathrm{pH} \\
\left(\mathrm{H}_{2} \mathrm{O}\right)\end{array}$ & $\begin{array}{c}\text { Total-C } \\
(\%)\end{array}$ & $\begin{array}{c}\text { Total-N } \\
(\%)\end{array}$ & $\begin{array}{c}\text { C.E.C. } \\
\mathrm{me} / 100 \mathrm{~g}\end{array}$ & $\begin{array}{c}\text { Clay } \\
\text { mineral }\end{array}$ & $\begin{array}{c}\text { Clay } \\
\text { content } \\
(\%)\end{array}$ & Texture \\
\hline Anjo & 53.5 & 6.2 & 1.75 & 0.15 & 10.0 & Kaolin & 45.2 & Lic \\
Nagano & 61.3 & 5.4 & 1.77 & 0.10 & 19.1 & $\begin{array}{c}\text { Montmo- } \\
\text { rillonite }\end{array}$ & 43.8 & Lic \\
Tochigi & 120.4 & 6.0 & 7.00 & 0.55 & 49.7 & Allophane & 22.3 & Lic \\
\hline
\end{tabular}


glass tubes was attached to the mouth of the tube and the glass tubes were closed, except when air was introduced once a day.

\section{Measurement of ${ }^{14} \mathrm{CO}_{2}$ Liberation}

To absorb a large portion of ${ }^{14} \mathrm{CO}_{2}$ liberated under the oxidative-flooded conditions, a small vessel containing $4 \mathrm{ml}$ of $10 \mathrm{~N} \mathrm{NaOH}$ was placed in the soil. $\mathrm{CO}_{2}$-free air was discharged into the flask at the rate of $200 \mathrm{ml} /$ min for 10 min once a day; air from the outlet was passed through toluene to trap volatile organic materials, and then through an alkali scintillator ${ }^{3)}$ to trap any ${ }^{14} \mathrm{CO}_{2}$ unabsorbed by the $\mathrm{NaOH}$ solution in the small vessel. The $\mathrm{NaOH}$ solution, the toluene trap and the alkali scintillator were renewed every day after air discharge, and radioassayed with Bray's liquid scintillator. ${ }^{3)}$

After each incubation period, $1 \mathrm{ml}$ of conc. $\mathrm{H}_{2} \mathrm{SO}_{4}$ was added to the soil, and air was bubbled through the soil. Any ${ }^{14} \mathrm{CO}_{2}$ liberated was trapped by the alkali scintillator and radioassayed.

To absorb ${ }^{14} \mathrm{CO}_{2}$ liberated from the reductive-flooded soil, a vessel containing $\mathrm{NaOH}$ solution was placed on the soil in a test tube. The $\mathrm{NaOH}$ solution was renewed periodically and radioassayed. After incubation, the soil was transferred to a flask and the ${ }^{14} \mathrm{CO}_{2}$ remaining in the soil was determined by the procedure described above.

\section{Extraction and Separation of Radioactive Compounds}

After ${ }^{14} \mathrm{CO}_{2}$ liberation, the soil was transferred into centrifuge tubes using $100 \mathrm{ml}$ of acetone and a small amount of water. The soil was shaken vigorously for $30 \mathrm{~min}$ and centrifuged, and the supernatant was taken out. The same extraction procedure was repeated. The acetone extracts were combined, concentrated, acidified with $\mathrm{HCl}$, and extracted with ether. The ether extract (Ether-I) was radioassayed. To the residual soil in the centrifuge tubes, $10 \mathrm{ml}$ of $1 \mathrm{~N} \mathrm{HCl}$ and $100 \mathrm{ml}$ of acetone were added. The mixture was then shaken and centrifuged, and the supernatant was taken out and neutralized with a $\mathrm{NaOH}$ solution. The acetone was evaporated and the residual solution was extracted with ether.
The ether extract (Ether-II) was radioassayed. Both ether extracts (I and II) were combined, dried with anhydrous $\mathrm{Na}_{2} \mathrm{SO}_{4}$ and concentrated for thin layer chromatography. The radioactivity of the residual soil was determined by the wet combustion method. ${ }^{3)}$

\section{Thin Layer Chromatography}

The concentrates of ether-extract were chromatographed on a silica gel plate (Merck $60 \mathrm{~F}_{254}$, precoated, $0.25 \mathrm{~mm}$ thick, $20 \times 20 \mathrm{~cm}$ ) with the reference compounds spotted on the radioactive materials. The solvent systems used and $R f$ values of the reference compounds are shown in Table 1. Spots of the reference compounds were detected under an UV lamp $(254 \mathrm{~nm})$, and the radioactive spots were detected by radioautography on X-ray film. The radioactive spots on the thin layer plates were collected and radioassayed.

The radioactivity was measured using a Packard Model 3320 liquid scintillation spectrometer by the external standard method.

\section{RESULTS}

The change in radiactivity of the acetone extracts and soil residues during incubation of the three soils is shown in Fig. 1. The radioactivity recovered from the soils by acetone extraction one $\mathrm{hr}$ after incubation was almost $100 \%$. The extractable radioactivity gradually decreased and the residual increased with time. However, the rates were extremely different between the oxidative and reductive conditions of the soils. The pattern for both mineral Anjo and Nagano soils was approximately the same, and the acetoneextractable radioactivity decreased much more rapidly under oxidative conditions than reductive conditions. The radioactivity of acetoneunextractable materials increased gradually with time, and reached 14 to $18 \%$ under reductive conditions and 50 to $52 \%$ under oxidative conditions 80 days after treatment. In Tochigi soil, however, the acetone-unextractable radioactivity increased slowly at almost equal rates under both conditions, although the extractable radioactivity decreased more rapidly under oxidative than reductive conditions.

In all cases, more than $99 \%$ of the radio- 

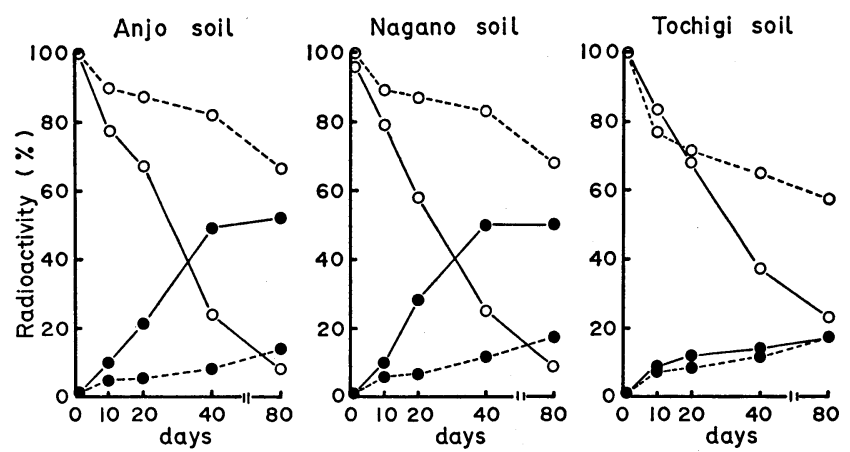

Fig. 1 Change in radioactivity extracted from the soils ( $\%$ of applied $\left.{ }^{14} \mathrm{C}\right)$. $\bigcirc$ : acetone extracts, $\bigcirc$ : soil residue, - oxidative flooded conditions, ...: reductive flooded conditions.
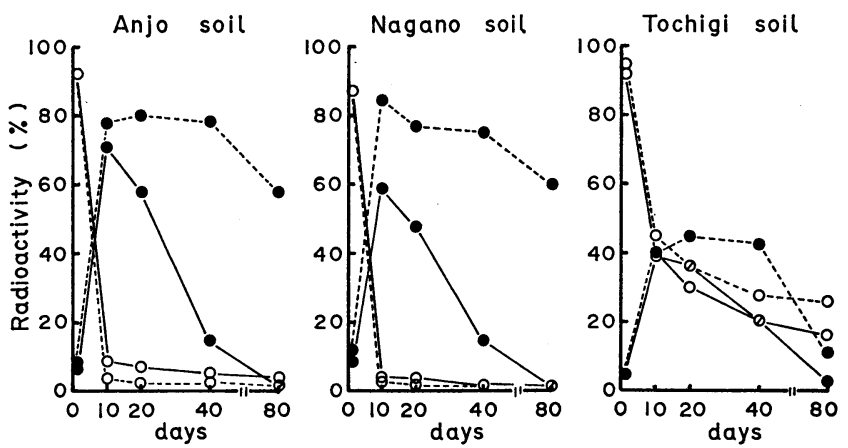

Fig. 2 Change in amounts of naproanilide and NPA in the soils ( $\%$ of applied $\left.{ }^{14} \mathrm{C}\right)$. $\bigcirc$ : Naproanilide, $\bullet$ : NPA, - : oxidative flooded conditions, $\cdots$ : reductive flooded conditions.

active materials in the concentrated acetoneextract solution was transferred into the ether, even 80 days after treatment.

Figure 2 shows the change in amounts of naproanilide and its major product, 1-(2naphthoxy)propionic acid (NPA), in the soils. Naproanilide decreased rapidly under both oxidative and reductive conditions, and a little more slowly in Tochigi soil than the two other mineral soils of Anjo and Nagano. The half-life of naproanilide was less than 10 days in all cases.

NPA reached 40 to $80 \%$ of applied radioactivity 10 days after the naproanilide treatment, then decreased rapidly under oxidative conditions but slowly under reductive conditions (Fig. 2). The decreasing rate of NPA under reductive conditions accelerated after 40 days.

More than seven degradation products were detected on thin layer chromatograms of the ether extracts, and the amounts of these products were always less than $2 \%$ of applied ${ }^{14} \mathrm{C}$-naproanilide (Table 3). These amounts did not vary significantly among the soils or between the conditions. No accumulation of these products was observed.

Only trace amounts of the radioactive volatile materials liberated from the soils were trapped in the toluene from the outlet air. Most of the ${ }^{14} \mathrm{CO}_{2}$ liberated from the soil was trapped by the $\mathrm{NaOH}$ solution in the small vessel in the incubation flask; only a negligible amount was trapped by the alkali scintillator solution in the second trap.

The ${ }^{14} \mathrm{CO}_{2}$ liberation from the soil was much larger under oxidative conditions than reductive conditions (Fig. 3). The amount liberated under oxidative conditions was seven times that under reductive conditions during the 
Table 3 Change in amounts of naproanilide and its degradation products in soils under flooded conditions.

(\% of applied radioactivity)

\begin{tabular}{|c|c|c|c|c|c|c|c|c|c|c|}
\hline \multirow{2}{*}{$\begin{array}{l}\text { Naproanilide and } \\
\text { degradation products }\end{array}$} & \multicolumn{5}{|c|}{ Oxidative flooded } & \multicolumn{5}{|c|}{ Reductive flooded } \\
\hline & $0^{\text {a })}$ & $\begin{array}{c}10 \\
\text { days }\end{array}$ & $\begin{array}{c}20 \\
\text { days }\end{array}$ & $\begin{array}{c}40 \\
\text { days }\end{array}$ & $\begin{array}{c}80 \\
\text { days }\end{array}$ & $0^{\text {a) }}$ & $\begin{array}{c}10 \\
\text { days }\end{array}$ & $\begin{array}{c}20 \\
\text { days }\end{array}$ & $\begin{array}{c}40 \\
\text { days }\end{array}$ & $\begin{array}{c}80 \\
\text { days }\end{array}$ \\
\hline \multicolumn{11}{|l|}{ Anjo Soil } \\
\hline Naproanilide & 92.4 & 9.0 & 7.6 & 5.8 & 4.1 & 92.8 & 4.6 & 3.2 & 3.0 & 1.7 \\
\hline $\left.\mathrm{NPA}^{\mathrm{b}}\right)$ & 9.2 & 71.3 & 58.3 & 15.1 & 1.3 & 6.7 & 78.0 & 80.4 & 78.5 & 58.1 \\
\hline $\mathrm{NPA}-\mathrm{Me}^{\mathrm{c})}$ & - & 0.3 & 0.3 & 0.1 & 0.1 & - & - & 0.1 & 0.1 & 0.3 \\
\hline 2-Naphthol & 一 & 0.9 & 1.1 & 0.4 & 0.2 & - & 0.6 & 1.0 & 1.0 & 0.7 \\
\hline 2,3-Naphthalenediol & - & 0.4 & 0.4 & 0.2 & - & - & 一 & 0.3 & 0.4 & - \\
\hline 2,6-Naphthalenediol & - & - & - & - & - & - & - & - & - & - \\
\hline 2,7-Naphthalenediol & - & 0.2 & 0.2 & 0.1 & 一 & - & -- & 0.1 & 0.2 & 一 \\
\hline $\begin{array}{l}\text { 2-Hydroxy-1,4- } \\
\text { naphthoquinone }\end{array}$ & - & 0.3 & 0.2 & 0.1 & 0.2 & - & 0.1 & 0.2 & 0.2 & 0.3 \\
\hline Other spots & 0.1 & 1.2 & 1.7 & 0.8 & 0.5 & 0.3 & 1.4 & 1.9 & 2.4 & 2.7 \\
\hline \multicolumn{11}{|l|}{ Nagano Soil } \\
\hline Naproanilide & 88.0 & 4.5 & 4.0 & 2.0 & 0.7 & 88.7 & 3.4 & 1.9 & 1.5 & 1.3 \\
\hline $\mathrm{NPA}^{\mathrm{b}}$ ) & 9.0 & 59.0 & 47.8 & 15.2 & 1.1 & 12.3 & 84.5 & 77.0 & 75.1 & 60.1 \\
\hline $\left.\mathrm{NPA}-\mathrm{Me}^{\mathrm{c}}\right)$ & 1.0 & 0.6 & 0.4 & 0.1 & 0.1 & - & 0.3 & 0.1 & 0.1 & 0.2 \\
\hline 2-Naphthol & 1.3 & 1.3 & 0.9 & 0.4 & tr. & - & 1.8 & 1.3 & 1.4 & 1.3 \\
\hline 2,3-Naphthalenediol & - & 一 & - & 一 & - & - & - & 0.2 & - & - \\
\hline 2,6-Naphthalenediol & 一 & - & 0.3 & - & - & - & - & 一 & - & - \\
\hline 2,7-Naphthalenediol & - & - & - & - & - & 一 & 一 & 0.1 & 一 & - \\
\hline $\begin{array}{l}\text { 2-Hydroxy-1,4- } \\
\text { naphthoquinone }\end{array}$ & 一 & 一 & 0.2 & 0.2 & 0.2 & 0.1 & 0.3 & 0.3 & 0.2 & 0.2 \\
\hline Other spots & 1.9 & 11.3 & 4.0 & 2.0 & 0.7 & 0.4 & 2.5 & 2.6 & 2.3 & 2.6 \\
\hline \multicolumn{11}{|l|}{ Tochigi Soil } \\
\hline Naproanilide & 92.2 & 39.9 & 30.0 & 21.1 & 15.8 & 94.9 & 44.8 & 36.7 & 28.7 & 26.1 \\
\hline$\left.N_{P A}{ }^{b}\right)$ & 4.8 & 39.9 & 36.6 & 21.0 & 3.3 & 5.2 & 41.1 & 45.5 & 42.8 & 11.7 \\
\hline $\mathrm{NPA}-\mathrm{Me}^{\mathrm{c})}$ & - & 0.3 & 0.5 & 0.1 & 0.2 & - & 0.2 & 0.2 & 0.2 & 0.3 \\
\hline 2-Napththol & - & 1.0 & 1.6 & 0.8 & 0.2 & - & 0.8 & 0.8 & 0.7 & 0.6 \\
\hline 2,3-Naphthalenediol & 一 & - & 0.2 & 一 & - & - & - & 0.2 & - & 一 \\
\hline 2,6-Naphthalenediol & - & - & - & - & - & - & - & 0.2 & - & - \\
\hline 2,7-Naphthalenediol & - & - & - & - & - & - & - & - & - & - \\
\hline $\begin{array}{l}\text { 2-Hydroxy-1,4- } \\
\text { naphthoquinone }\end{array}$ & - & 0.2 & 0.1 & 0.1 & - & 0.1 & 0.3 & 0.1 & 0.1 & 0.2 \\
\hline Other spots & 0.5 & 1.4 & 1.2 & 0.7 & 0.5 & 0.2 & 1.4 & 1.1 & 1.2 & 0.7 \\
\hline
\end{tabular}

a) One hour after treatment, b) 1-(2-Naphthoxy)pronionic acid, c) Methyl 1-(2-naphthoxy)propionate.
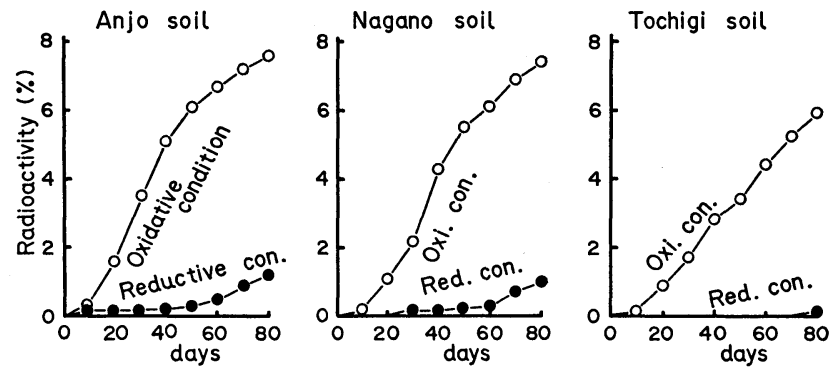

Fig. $3{ }^{14} \mathrm{CO}_{2}$ evolution from soils treated with ${ }^{14} \mathrm{C}$-naproanilide. 
80 days of incubation.

\section{DISCUSSION}

The degradation of naproanilide was studied under both aerobic and anaerobic flooded conditions. The three paddy soils used for this study were selected to have common but different properties as shown in Table 2. It is well known that flooded soils are rapidly reduced, except for the oxidative layer in the surface $0.5-1 \mathrm{~cm}^{4}{ }^{4}$ In this study, Eh values of the soils after preincubation were $+500 \sim$ $+600 \mathrm{mV}$ under aerobic conditions, and -270 , -250 , and $-100 \mathrm{mV}$ for Anjo, Nagano, and Tochigi soils, respectively, under anaerobic conditions.

Naproanilide in each type of soil was degraded rapidly at almost equal rates under both oxidative and reductive conditions to produce a large amount of NPA (Fig. 2). This indicates that the hydrolysis of naproanilide to NPA in the soils is not affected by the redoxy condition of soil. The degradation rate of naproanilide was not different between Anjo and Nagano soils, but it was a little slower in Tochigi soil, which is a humus volcanic ash soil. Therefore, the hydrolysis of naproanilide does not seem to be much affected by soil pH, C.E.C., clay minerals (Table 2), and in also little affected by humus content. This may be due to the adsorption of naproanilide on humus of Tochigi soil, because many lipophylic pesticides are adsorbed on humus and the adsorption delays the degradation of pesticides in many cases.

${ }^{14} \mathrm{C}$-Naphthalene-labelled NPA was degraded rapidly to produce ${ }^{14} \mathrm{CO}_{2}$ under oxidative conditions. Under reductive conditions, however, the NPA degradation was slower and ${ }^{14} \mathrm{CO}_{2}$ liberation was much less, although the degradation was accelerated after 40 days of incubation (Figs. 2 and 3). Therefore, the degradation of NPA may be largely affected by the redoxy condition of the soil.

The degradation products other than NPA in acetone extracts were 2-naphthol and its hydroxylated compounds, and NPA methyl ester and several unidentified products (Table 3). Each of these products was less than $2 \%$ of the applied amount of naproanilide in all cases, and no accumulation was observed for any of the degradation products. On the other hand, fairly large portions of the radioactivity remained as acetone-unextractable or soilbound residues after the decrease in NPA (Figs. 1 and 2). The amounts of the acetoneunextractable residues were far larger under oxidative conditions in which NPA was degraded more rapidly, except in Tochigi soil where the soil-bound residues accumulated at small but similar rates under both oxidative and reductive conditions. The amount of NPA was not much different under the two conditions.

These results may indicate that NPA produced is degraded more rapidly under oxidative conditions and more slowly under reductive conditions to produce $\mathrm{CO}_{2}$ and soil-bound residues through 2-naphthol and then naphthalenediols. On the degradation pathway, the esterification of NPA and the quinone formation from naphthalenediols may also occur. Hydroxylation of 2-naphthol occurred at various portions including probably 1 and/ or 4 positions, because 2-hydroxy-1,4-naphthoquinone was found as a product, but naphthalenediols other than 2,3-, 2,6-, and 2,7-dihydroxynaphthalene were not examined as authentic compounds for identification. The esterification of NPA may be reversible because esters of many compounds including 2,4-D esters $^{5)}$ and bifenox ${ }^{6)}$ are easily hydrolyzed to the free acid in the soil. The degradation of 1-naphthol and the subsequent production of 1,2-naphthalenediol in soil by microorganisms were well illustrated in the study of the degradation of carbaryl. ${ }^{7,8)}$ The direct splitting of ether linkage of naproanilide to 2-naphthol may be a minor pathway even if it occurs, because a large portion of the acetone-extract was NPA during the whole incubation period, especially in the mineral soils. The possible degradation pathways of naproanilide are shown in Fig. 4.

A number of reports on the degradation of anilide herbicides, such as propanil, dicryl, solan, and butachlor, have been published. ${ }^{9}$ The anilide linkage of these anilides, except $N$-alkyl acylanilide such as butachlor, ${ }^{10}$ is readily hydrolyzed by soil microorganisms. ${ }^{9)}$

The fate of aniline produced from naproanilide was not studied. A large portion of 


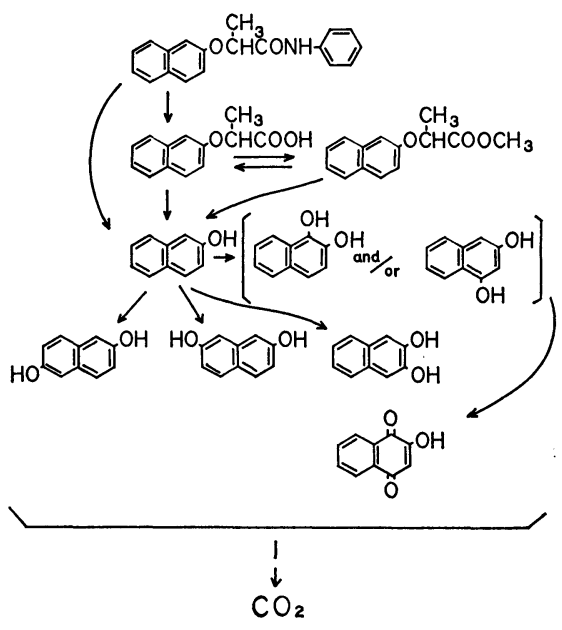

Fig. 4 Possible degradation pathways of naproanilide in soil.

aniline produced may be adsorbed on soil particles and gradually degraded, like many other aniline derivatives produced from anilide and carbamate herbicides ${ }^{9)}$ and diphenyl ether herbicides. ${ }^{2}$ The properties of soil-bound residues produced from naproanilide have not yet been studied.

\section{REFERENCES}

1) Y. Takasawa, K. Igarashi \& T. Takematsu: Proceedings of the Fifth Asian-Pacific Weed Science Society Conference, p. 96, 1976

2) M. Oyamada \& S. Kuwatsuka: J. Pesticide Sci. 4, 157 (1979)

3) K. Kametani, Y. Inoue \& K. Maruyama: Rudioisotopes 16, 607 (1967)

4) F. N. Ponnamperuma: "Advances in Agronomy," Vol. XXIV, Academic Press, New York and London, p. 29, 1972

5) A. S. Smith: Weed Res. 12, 364 (1972)

6) H. Ohyama \& S. Kuwatsuka: J. Pesticide Sci.
3, 4.01 (1978)

7) H. Kazano, P. C. Kearney \& D. D. Kaufman: J. Agric. Food Chem. 20, 975 (1972)

8) J. I. Davies \& W. C. Evans: J. Biochem. 91, 251 (1964)

9) D. D. Kaufman: "Pesticides in Soil and Water," ed. by E. D. Cuenzi, Soil Sci. Soc. of America, Inc., publisher Madison, Wisconsin, USA, p. 159, 1974

10) Y-L. Chen \& T-C. Wu: J. Pesticide Sci. 3, 411 (1978)

要約

\section{酸化的および還元的条件下の湛水土䁃中にお ける除草剤ナプロアニリド [1-(2-naphthoxy) propionanilide] の分解}

小山田正美，五十嵐桂一，錹塚昭三 ナフタレン環を ${ }^{14} \mathrm{C}$ で標識したナプロアニリド除草䬉 の土壌中での分解に関与する土塨要因の影響打よび分解 生成物について, 室内実験により研究した。理化学的性 質の異なる 3 種類の土塎を酸化的および還元的な湛水状 態とし，その土塨中に扔けるナプロアニリドの分解を比 較すると，土塨により若干の差はあるが，酸化還元のい

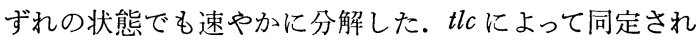
た分解生成物は, 主要代謝物として 1-(2-naphthoxy)propionic acid (NPA) が同定され，他に微量の methyl 1-(2-naphthoxy)propionate, 2-hydroxynaphthalene, 2-hydroxy-1,4-naphthoquinone および 2,3-, 2,6-, 2,7-の各 dihydroxynaphthalene が検出された. 多量 に生成した NPA は還元条件よりも酸化条件下で速やか に分解した，その他の分解生成物はきわめて微量で，各 土塨間および土塨の酸化還元の状態の間で顕著な差異は 認められなかった，最終的にはナフタレン環が開裂して ${ }^{14} \mathrm{CO}_{2}$ が生成するが，その生成は還元的湛水状態よりも 酸化的湛水状態のほうが速かった．また，かなりの量の 放射能がフセトンでは抽出できない土㙵結合体として残 った。 